\title{
Pembuatan Alat Angkut Tradisional Berbasis Bahan Bekas untuk Membantu Kelompok Tani di Lahan Gambut Kabupaten Pulang Pisau
}

\author{
Making Traditional Transport Equipment Based on Used Material to Help Farmers' Groups in \\ Peatlands, Pulang Pisau Regency
}

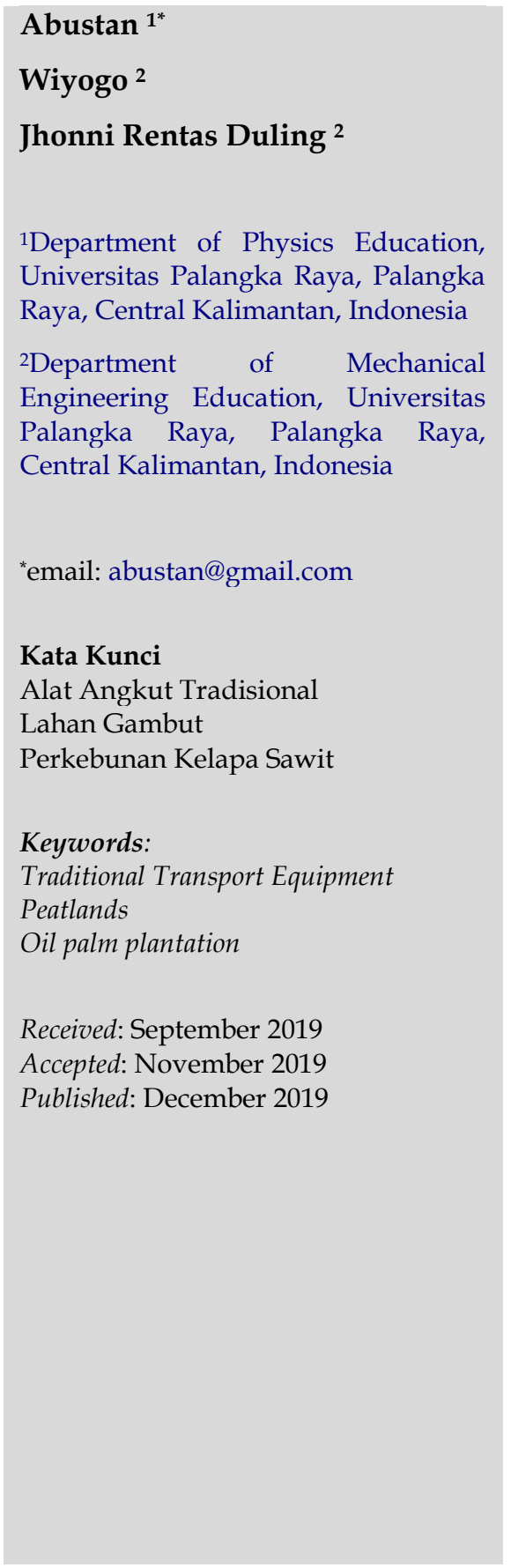

\begin{abstract}
Abstrak
Perkebunan kelapa sawit yang berada di lahan gambut tingkat keasamannya tinggi, memiliki struktur tanah yang tidak stabil. Pada musim penghujan, permukaan tanahnya cenderung licin dan menempel pada alas kaki atau ban kendaraan. Sementara pada musim kemarau kondisi tanahnya kering, mudah terbakar serta berdebu, terlebih jika dilewati kendaraan roda empat dengan bobot dan ukuran yang besar. Petani mengangkut hasil panen buah sawit menggunakan alat angkut ukuran kecil, sejenis arco kapasitas 50-70 kg, drum plastik kapasitas 40$50 \mathrm{~kg}$, dan lanjung kapasitas 30-40 kg. Proses pengangkutan buah sawit dari panen hingga sampai pabrik memerlukan waktu cukup lama, berpotensi merugikan petani akibat buah restan (biji sawit lepas dari tangkainya). Penyebab utamanya adalah alat angkut yang digunakan bervolume kecil dan dan dikerjakan dengan tenaga manusia. Buah sawit agar tetap segar sampai di pabrik pengolahan dengan durasi waktu tidak lebih $2 \times 24$ jam, apabila terlambat petani mengalami kerugian sebesar 10$15 \%$ karena bobot timbangan menyusut. Telah dilakukan inovasi alat angkut tradisional hasil modifikasi berkapasitas $500-750 \mathrm{~kg}$ berbasis bahan bekas menggunakan desain khusus memperhitungkan kapasitas angkut, tenaga pekerja, kondisi jalan, dan ketepatan waktu agar buah tidak menjadi restan. Petani sangat terbantu baik dari segi tenaga, proses (waktu), transport volume, serta dapat dioperasikan dilahan gambut baik musim hujan atau musim kemarau.
\end{abstract}

\begin{abstract}
Oil palm plantations on peatlands have a high acidity level and have an unstable soil structure. In the rainy season, the land surface tends to be slippery and stick to vehicle footwear or tires. While in the dry season, the soil is dry, flammable, and dusty, especially if it is passed by a fourwheeled vehicle with a significant weight and size. Farmers transport the harvest of palm fruit using a small size conveyance, a type of "arco" capacity $50-70 \mathrm{~kg}$, plastic drum capacity $40-50 \mathrm{~kg}$, and peninsula capacity $30-40 \mathrm{~kg}$. The process of transporting palm fruit from harvest to the mill takes a long time, potentially harming farmers due to "restan fruit" (palm oil is loose from the stem). The leading cause is the conveyance that is used in small volumes and is done by human labor. Palm fruit to stay fresh arrived at the processing plant with a duration of no more than $2 \times 24$ hours, if late farmers experience a loss of $10-15 \%$ because the weight of the scales is shrinking. Innovation of traditional conveyance capacity 500-750 $\mathrm{kg}$ based on used materials has been carried out using a special design that takes into account the carrying capacity, labor, road conditions, and timeliness so that the fruit does not become "restan." Farmers are much helped both in terms of energy, process (time), transport volume, and can be operated on peatlands in both the rainy or dry season.
\end{abstract}




\section{PENDAHULUAN}

Masyarakat tani di Kabupaten Pulang Pisau dan di beberapa kabupaten lainnya di wilayah Kalimanntan Tengah masih banyak mengalami kendala atau kesulitan dalam mengangkut hasil produksinya untuk dipasarkan. Kesulitan saat mengambil hasil panen pada lahan pertanian mereka, termasuk disaat akan memobilisasi pekerja menuju ke tempat kerjanya di lahan perkebunan (Pudjianto, 2006). Petani pada umumnya mengambil dan mengangkut hasil panennya dengan cara memanggul menggunakan Lanjung yaitu sejenis tempat untuk mengangkut buah atau wadah yang terbuat dari anyaman rotan yang dibawa dengan cara dipanggul sambil berjalan menuju tempat penumpukan di pinggir parit atau di pinggir jalan yang dapat diakses oleh kendaraan, selanjutnya akan diangkut dengan menggunakan kelotok atau mobil. Tempat atau wadah semacam ini digunakan oleh sebagian warga untuk membawa hasil panen mereka sampai ke rumah walaupun harus bejalan 2 hingga 3 kilometer dari kebun.

Pemandangan semacam ini juga dapat dijumpai di lokasi kebun milik petani mandiri atau milik kelompok tani yang telah bekerja secara bersama-sama dalam mengatasi permasalahan di lokasi perkebunan mereka, termasuk masalah pengangkutan hasil produksi. Kelompok tani semacam ini banyak dijumpai pada perkebunan kelapa sawit, perkebunan karet, dan perkebunan dengan hasil komoditi yang lainnya (Kamuntuan et al., 2017; Hermanto \& Swastika, 2011). Kabupaten Pulang Pisau termasuk daerah dimana masyarakatnya banyak bekerja pada sektor agraria khusunya di perkebunan guna menutupi kebutuhan hidup sehari-hari dan meningkatkan taraf hidup mereka. Kegiatan masyarakat selain di sektor perkebunan ini juga banyak dijumpai berupa menanam padi gunung, jagung, dan jenis lainnya, yang semuanya memerlukan angkutan untuk sampai pada tempat penampungan akhir walaupun dalam jumlah luasan yang tidak luas karena areal yang terbatas (Darwis \& Nurmanaf, 2004).

Hasil panen dari perkebunan kelompok tani pada beberapa daerah selanjutnya diangkut dengan menggunakan alat angkut sederhana, yang diwariskan oleh nenek moyang mereka. Alat ini menjadi ciri khas suku dayak di pedalaman pulau Kalimantan. Alat angkut tradisional ini bernama Lanjung yang terbuat dari anyaman rotan, biasanya disandang dibelakang pinggul seperti halnya membawa ransel, namun alat angkut ini kapasitasnya sangat terbatas hanya $30-40 \mathrm{~kg}$ untuk sekali angkut (Gambar 1). Memanggul lanjung sambil berjalan di tengah kebun dengan beban seberat itu bukan hal yang mudah, apalagi jika dilakukan berulang-ulang untuk mengangkut buah yang banyak sehingga nilai efektivitasnya masih tergolong rendah.

Petani juga biasa menggunakan drum plastik (Gambar 2) yang dibelah dua dengan kapasitas $40-50 \mathrm{~kg}$, lalu ditarik dari dalam kebun mendekati parit untuk dinaikkan di atas kelotok menuju tempat pemasaran. Alat angkut drum plastik yang dibelah dua ini juga kapasitasnya terbatas, untuk sekali ditarik. Penggunaan drum plastik ini sistemnya diikat dengan tali yang kuat lalu ikatkan pada badan kemudian ditarik dengan menggunakan kekuatan badan dan pijakan kaki. Drum plastik sedikit lebih praktis dibandingkan sejenis alat angkut semacam Lanjung, namun kendala utama yang dihadapi pekerja adalah ketika menarik ditengah areal yang tidak rata dan bergelombang, membuat drum plastik tadi sulit digerakkan, apalagi diisi dengan beban yang berat. Pekerjaan semacam ini akan menguras tenaga buruh atau pekerja yang berdampak pada terbatasnya kemampuan mengangkat dalam sehari.

Petani biasanya juga mengunakan alat sejenis arco (Gambar3), alat angkut ini memiliki kapasitas sekitar 50- 
$60 \mathrm{~kg}$ untuk sekali muat, dan alat ini bisa meringankan beban petani dalam mengeluarkan hasil panen di kebun. Namun, kendalanya adalah sulit ditarik/didorong jika jalan tidak datar, kapasitas angkut yang terbatas, dan tidak dapat di dorong pada lahan gambut apalagi pada musim hujan, karena disamping bannya yang kecil membuat lebih mudah tenggelam di lahan gambut yang basah, serta juga bisa terhalang dengan semak atau rumput ilalang, dan sejenisnya yang banyak dijumpai di dalam areal perkebunan masyarakat tani.

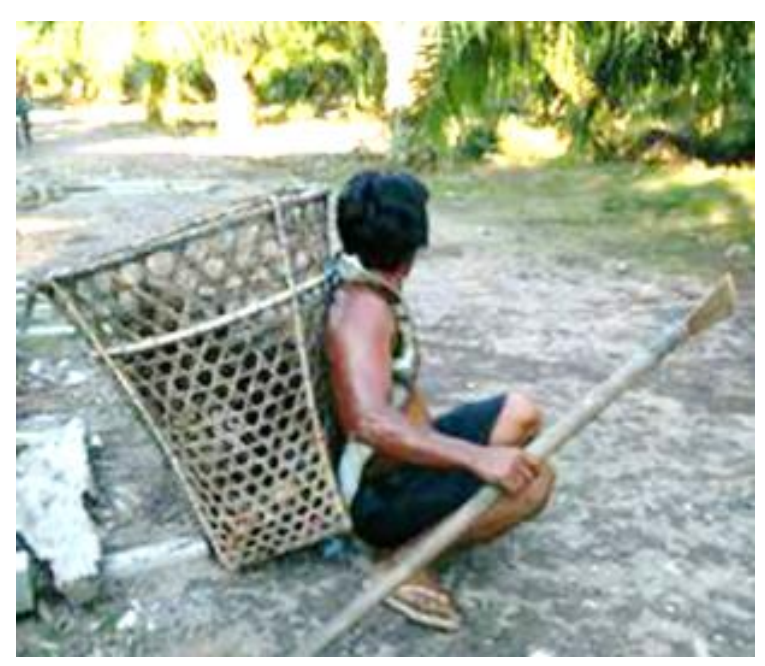

Gambar 1. Lanjung

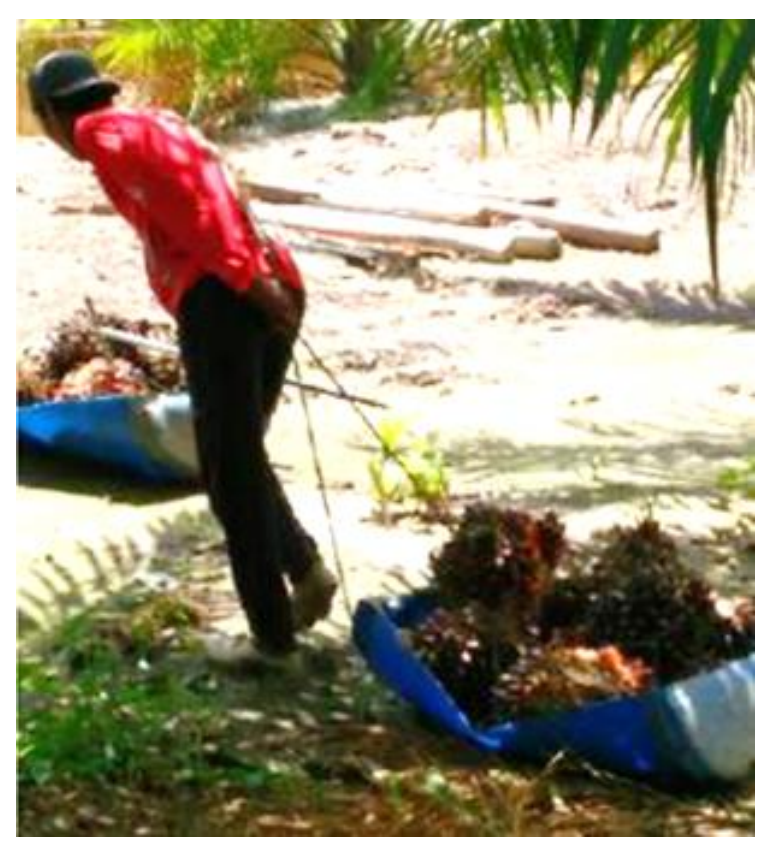

Gambar 2. Drum plastik

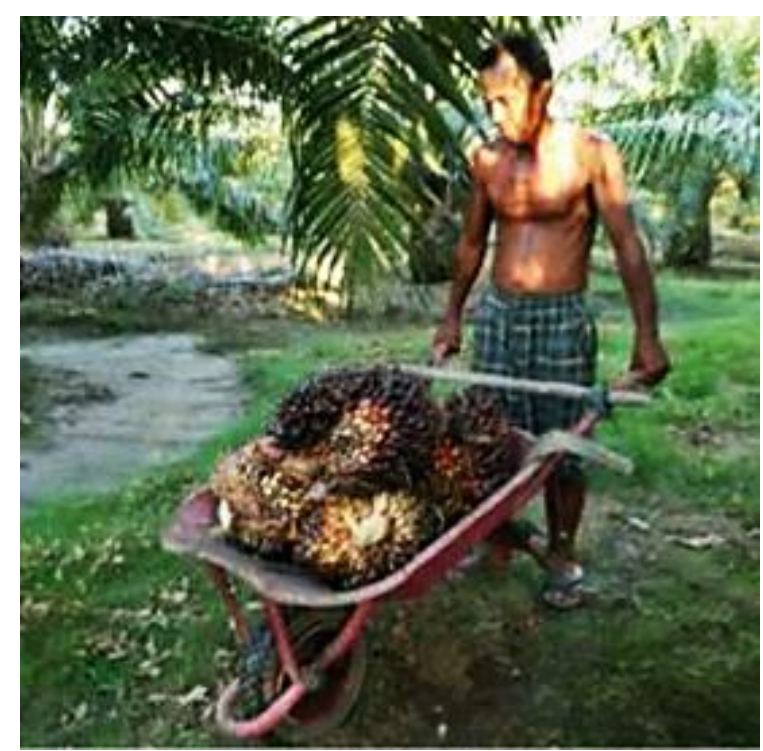

Gambar 3. Arco

Melihat kondisi di atas, jika dilihat dari faktor efisiensi dan efektifitasnya sudah tentu tidak ekonomis, disamping kapasitas angkut yang terbatas, tenaga yang harus prima, juga waktu angkut yang lama, karena harus diangkut berulang-ulang. Proses pengangkutan akan semakin lama apabila hasil panen yang diperoleh petani semakin banyak (Gunawan et al., 1998). Gambaran yang dapat dipaparkan berdasarkan hasil survey di lapangan pada salah satu perkebunan kelapa sawit milik kelompok tani "Pelangi Nusantara" di kecamatan Anji, Kabupaten Pulang Pisau bahwa dalam areal perkebunan kelapa sawit dengan luasan $10 \mathrm{Ha}$, pada saat panen dibutuhkan waktu tiga hari untuk mengeluarkan dan mengangkut buah sebanyak $7.075 \mathrm{~kg}$ atau sekitar 7 ton yang diangkat oleh pekerja sebanyak tiga orang, satu orang pekerja rata-rata mengangkat buah sebanyak 786 $\mathrm{kg}$ per hari. Kondisi ini dinilai sangat lamban dan sangat tidak efektif serta dapat merugikan pekerja serta pemilik buah sawit yang saat itu sedang dipanen buahnya. Kerugian ini meliputi waktu kerja yang lama, tenaga yang dikeluarkan oleh pekerja, dan menurunnya kualitas buah sawit yang dipanen, semuanya akan bermuara pada nilai finansial yang harus dikeluarkan oleh kelompok tani (Colchester et al., 2011). 
Gambaran nilai finansial yang dapat diprediksi sebagai bentuk kerugian jika kelompok tani menggunakan alat seperti yang dipaparkan di atas adalah (1) merosotnya kualitas buah (buah membusuk) karena berada dipenumpukan sementara yang cukup lama, banyak berondolan, banyak ditemukan janjang kosong, dan jika kondisi ini sampai pada pabrik sebagai tempat penjualan buah, akan mendapat potongan harga sebesar 10-15\%. Besar jumlah potongan jika dikaitkan dengan hasil panen kelompok tani Pelangi Nusantara $7.075 \mathrm{~kg}$, maka potongannya mencapai $495-700 \mathrm{~kg}$ yang jika dikonversi dengan nilai uang maka yang terpotong mencapai Rp.850.000,- hingga Rp.1.225.000,-. Artinya seharusnya kelompok tani Pelangi Nusantara dari hasil panen tersebut, bisa memperoleh uang sebesar Rp.12.381.250.karena keterlambatan proses sampainya buah ditempat pabrik maka kelompok tani tersebut hanya menerima sebesar Rp. 11.531.250, bahkan bisa lebih kurang jika yang terpotong mencapai $15 \%$. (2) banyaknya dana yang harus dikeluarkan untuk membayar pekerja apalagi jika sistem pengupahan menggunakan upah harian, artinya jika dari jumlah buah sawit yang dikeluarkan sebesar $7.075 \mathrm{~kg}$, selama tiga hari untuk tiga orang pekerja dengan upah harian sebesar Rp.100.000,- per orang, maka total upah yang harus dikeluarkan adalah Rp.900.000.- atau Rp.300.000.- perorang, seharusnya cukup mengeluarkan sebesar Rp.300.000 untuk tiga orang bukan Rp.900.000.-, artinya kondisi ini dinilai tidak efisien dari segi pembayaran upah pekerja. (3) banyak menguras tenaga pekerja (Suharyanto et al., 2016; Irawati \& Yantu, 2015).

Permasalahan di atas sesungguhnya dapat diatasi jika para petani sawit, khususnya yang tergolong pada kelompok tani dalam melakukan aktivitasnya menggunakan alat angkut sederhana yang dapat dibuat dengan menggunakan bahan-bahan bekas dari rongsokan mobil yang tidak lagi berfungsi dan telah dijadikan tumpukan besi tua dengan jalan mengambil dan memanfaatkan beberapa komponennya seperti gerbok (perumahan gigi transmisi), gardang (penggerak roda belakang) mobil, velg, tromol, kampas rem, stir, pedal kopling, pedal gas, pedal rem, serta tongkat persneling (Pratama et al., 2016). Komponen barang bekas inilah yang akan difungsikan sebagai bagian utama untuk membuat alat angkut tradisional yang dapat membantu kelompok tani dalam melakukan aktivitasnya. Mesin penggerak yang akan digunakan adalah mesin Kubota atau Yanmar yang kekuatannya disesuaikan dengan daya angkut alat yang dibuat. Daya angkut alat ini bisa mencapai $750 \mathrm{~kg}$ hingga $1000 \mathrm{~kg}$. Kapasitas tersebut dapat disesuaikan dengan kondisi lapangan dimana akan dioperasikan.

Kondisi di atas merupakan suatu permasalahan yang amat serius dan perlu segera diberikan jalan keluarnya, khususnya bagi kelompok tani yang melakukan kegiatan perkebunan kelapa sawit di lahan gambut. Ketidakmampuan mereka mencari solusi atas permasalahan tersebut, membuat mereka pasrah menerima keadaan yang berlanjut terus menerus. Para kelompok tani akan selalu kehilangan haknya untuk memperoleh bayaran yang penuh dari hasil panen mereka hanya karena sering mendapat potongan persen dari buah yang dipanen. Potongan ini disebabkan karena menurunnya kualitas barang, lamanya diproses pemanenan sampai dipenumpukan, yang berakibat banyaknya janjang kosong, membusuknya buah karena kelamaan proses pemanenan sampai pada pengiriman ke pabrik pengolahan.

Penentuan permasalahan mitra yang prioritas adalah (1) mengatasi keterlambatan pengeluaran buah sawit dari lahan perkebunan ke penumpukan sementara. (2) mengatasi terjadinya pemotongan berat buah karena kualitas buah sawit menurun, (3) mengatasi pembayaran upah kerja yang berulang-ulang, serta (4) meringankan 
beban kerja para buruh. Keempat aspek ini merupakan hal yang mendasar dan menjadi kesepakatan bersama antara mitra (kelompok tani) dengan tim pelaksana pengabdian kepada masyarakat. Pengabdian ini akan dilaksanakan dengan melibatkan dosen dan mahasiswa pada program studi Pendidikan Teknik Mesin dan Fisika di Universitas Palangka Raya. Mahasiswa yang dimaksudkan adalah mahasiswa yang telah menempuh minimal 130 SKS, dan telah diberikan pembekalan singkat tentang kondisi serta situasi baik lokasi penelitian maupun permasalahan yang dihadapi oleh masyarakat kelompok tani. Keterlibatan mahasiswa dan dosen dari Teknik mesin akan menambah hubungan sosial dan kemasyarakatan antara petani dengan dosen dan mahasiswa.

\section{METODOLOGI}

Metode yang ditawarkan meliputi persiapan awal, menyiapkan semua komponen yang diperlukan dalam pembuatan alat angkut tradisional ini yang meliputi komponen onderdil mobil yang tidak terpakai lagi (telah menjadi bahan ronsokan) yang berupa: (1) gardan, (2) casis, (3) tromol dan cakram, (4) per belakang, (5) gerbok atau rumah persneling, (6) tongkat persneling, (7) pedal rem, kopleng, pedal gas, (8) stir atau alat kemudi, (9) velg ukuran 13 inch, (10) bak rem, dan (11) tali kopleng, tali gas, dan tali rem.

Persiapan untuk kelengkapan utama, adapun komponen utama meliputi: (1) Mesin penggerak sejenis mesin merek Kubota, atau Yanmark dengan tenaga sebesar 10 PK yang dapat dijumpai dengan mudah dipasaran, (2) besi plat dengan berbagai ukuran luasannya untuk keperluan pembuatan bak belakang sebagai wahana angkutan, (3) besi siku dengan ketebalan 3-5 mm, (4) velg dan ban bekas ukuran 13 inch yang sesuai dengan velg yang sudah disiapkan terlebih dahulu, (5) alat pemotong besi plat, dan (6) mesin las untuk melakukan pengelasan atau penyambungan komponen yang digunakan.

Persiapan untuk kelengkapan tambahan, kelengkapan tambahan meliputi kabel dengan berbagai jenis ukuran untuk keperluan elektrik dari pergerakan arus listrik untuk menyalakan lampu utama dan lampu reting serta lampu stop jika diperlukan. Adapun tahapan pelaksanaan dibagu menjadi delapan tahap, yaitu:

1. Tahap pertama meliputi perakitan Chasis. Chasis disesuaikan dengan kebutuhan kapasitas alat angkut yang akan dibuat, untuk keperluan kapasitas 500 hingga $750 \mathrm{~kg}$ barang atau buah ukuran Chasis dapat dibuat dengan panjang $390 \mathrm{~cm}$ sedangkan lebar 120 $\mathrm{cm}$.

2. Tahap kedua meliputi pembuatan bak belakang dengan ukuran panjang $210 \mathrm{~cm}$, dan lebar $150 \mathrm{~cm}$, serta tinggi $85 \mathrm{~cm}$. Bak dirakit di atas Chasis yang sudah disiapkan dan telah ditandai dengan ukuranukuran yang sudah dipersiapkan terlebih dahulu. Peletakan atau perakitan bak ini jika diangggap sudah sesuai dengan ukuran selanjutnya dilakukan pengelasan dan pembautan agar diperoleh pegangan bak pada Chasis yang kokoh.

3. Tahap ke tiga meliputi pembuatan peletakan pondasi mesin penggerak yang menyesuaikan dengan kondisi kedudukan mesin di atas Chasis. Tahap ini diperlukan pengukuran yang sangat teliti dan harus tepat posisi kedudukan mesin penggerak, karena akan di koneksikan dengan gerbok atau rumah persenelang yang akan dipasang.

4. Tahap ke empat pemasangan gerbok persenelang dan blok penggerak roda belakang, sebelum pemasangan ini terlebih dahulu pemasangan peer belakang dan peer bagian depan serta pemasangan gerdang serta blok yang menghubungkan gerbok (rumah persneling). Semua komponen apabila telah terkoneksi dengan baik dan dipastikan tidak ada 
yang salah dalam pemasangan, maka terlebih dahulu dilakukan pengecekan oleh orang yang memiliki kemampuan pengetahuan di bidang otomotif dengan melibatkan dosen dari teknik mesin.

5. Tahap ke lima pemasangan tali panbel ukuran B 53 yang dianggap paling sesuai dengan ukuran mesin serta ukuran kapasitas angkut yang akan dibuat. Tali panbel yang digunakan sebanyak 2 buah. Tali panbel yang dipasang akan dihubungkan dengan poros penggerak yang telah dipasang sebelumnya pada gerbok atau rumah persneling.

6. Tahap ke enam pemasangan roda atau ban yang telah disiapkan, ban yang digunakan adalah ban ukuran kecil atau ukuran 13 inch untuk menyesuaikan dengan kondisi jalan serta beban angkut dari alat yang dibuat. Selanjutnya adalah pemasangan pedal, kopleng, pedal gas dan pedal rem. Komponen ini akan dipasang secara bersamaan untuk memudahkan pekerjaan. Pedal gas akan dihubungkan dengan tali gas yang ada pada mesin penggerak utama, sedangkan pedal rem akan dihubungkan dengan termol (perumahan kampas rem) bagian belakang dan yang ada di depan. Langkah terakhir adalah pemasangan pedal kopleng, pedal kopleng ini merupakan kunci utama berhasil atau tidaknya pekerjaan yang dibuat. Pedal ketika di injak akan menekan tali panbel ke bawah sehingga akan menyentuh putaran poros gigi pada persenelang, ketika tali panbel menyentuh poros gigi maka secara otomatis gigi persenelang akan berputar, seiring dengan berputarnya blok yang akan menggerakkan ban belakang.

7. Tahap ke tujuh adalah pengecetan, proses pengecetan dapat dilakukan dengan penyemprotan langsung dengan menggunakan mesin duco atau kompressor yang biasa digunakan oleh tukang cat, barang ini dapat dipinjam sementara kurang lebih 2 hari. Pengecetan juga dapat menggunakan alat atau bahan apa adanya seperti kuas untuk melapisi plat besi yang terpasang pada bodi guna menghindari percepatan terjadinya korosi.

8. Tahap ke delapan (terakhir) adalah pemasangan lampu-lampu yang diperlukan khususnya lampu utama, dan lampu stop serta reting. Selanjutnya, setelah selesai semua pekerjaan ini baru dilakukan uji coba jalan.

\section{HASIL DAN PEMBAHASAN}

Hasil yang diperoleh dari kegiatan ini adalah ada produk yang dapat ditampilkan dan digunakan oleh petani mitra berupa alat angkut sederhana dengan menggunakan bahan baku yang dapat diperoleh dari barang bekas kendaraan roda empat yang tidak berfungsi lagi. Dasar untuk mengembangkan dan menyempurnakan baik dari segi model, kapasitas angkut, dan penggunaannya ke arah yang lebih baik dan lebih multiguna. Meningkatkan produktivitas dan pendapatan pekerja atas peningkatan segi volume kerja, tenaga, dan lebih efektif serta waktu yang lebih efisien. Selain itu juga untuk menjamin kualitas buah yang sampai pada pabrik (tidak restan) karena dapat mempersingkat proses dari aspek mobilisasi buah. Adapun tampilan dari alat angkut yang telah selesai dirakit disajikan pada Gambar 4 sampai Gambar 7, masing-masing dengan tampilan dari tampak depan kanan, depan kiri, tampak samping, dan juga tampak belakang. 


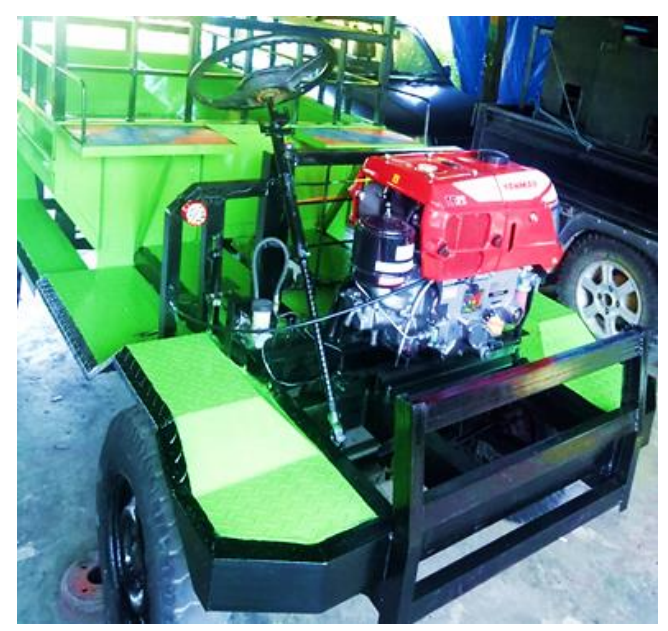

Gambar 4. Alat Angkut Tampak Depan Kanan

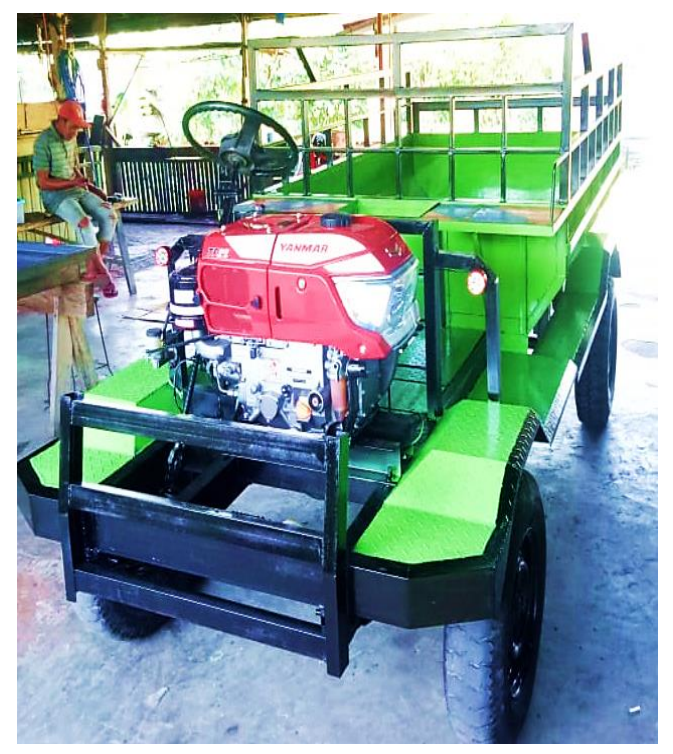

Gambar 5. Alat Angkut Tampak Depan Kiri

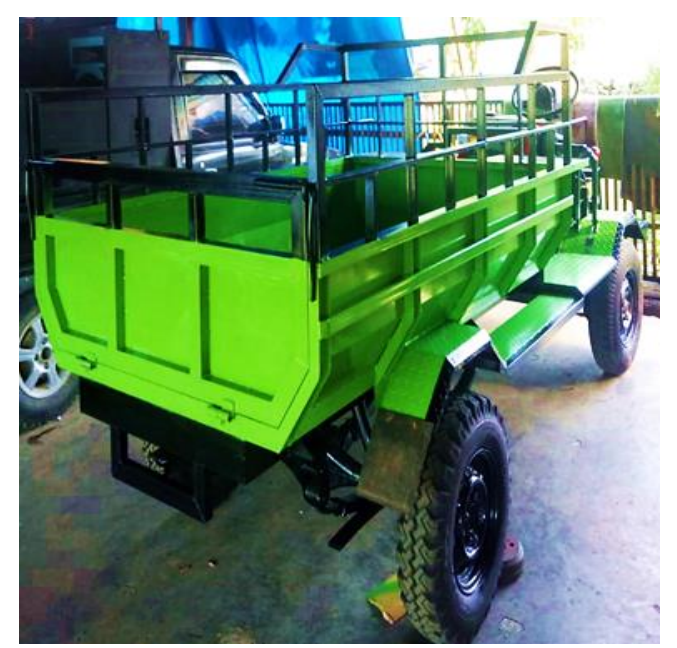

Gambar 6. Alat Angkut Tampak Samping

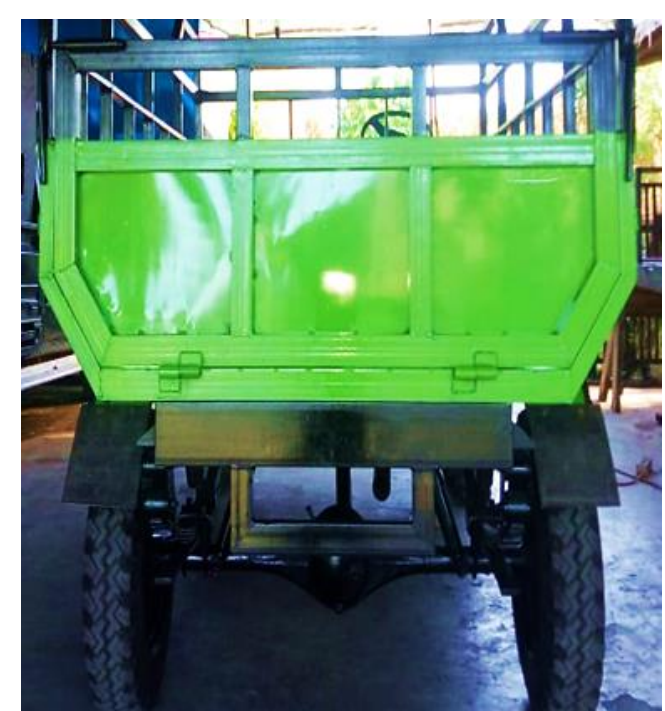

Gambar 7. Alat Angkut Tampak Belakang

Luaran yang diharapkan dari kegiatan ini adalah (1) menciptakan alat angkut tradisional yang berkapasitas $500-750 \mathrm{~kg}$ berbasis barang bekas sebagai moda transpotasi alternatif buat petani, dinilai sangat efektif pada areal perkebunan kelapa sawit di lahan gambut, (2) meringankan beban kerja masyarakat tani, termasuk para kelompok tani yang berkecimpung di perkebunan kelapa sawit dengan skala mikro, (3) mempercepat pengangkutan buah sawit dari proses pemanenan sampai di tempat penumpukan sementara sebelum menuju tujuan akhir, guna menghindari pemotongan harga terhadap buah yang ada karena menurunnya kualitas buah sampai di pabrik, (4) buah sawit segar yang selalu diharapkan oleh pembeli atau pihak pabrik tetap terjaga dengan baik. Kualitas buah ketika sampai di pabrik sangat baik (tandan segar) maka harga yang diberikan dari pihak pabrik juga cukup bagus, maka pendapatan petani meningkat, (5) memperoleh hak cipta atas hasil yang didapatkan dengan membuat alat angkut untuk petani (Fadhil et al., 2015).

Pengabdian kepada masyarakat ini di rancang dengan pertimbangan bahwa seluruh perencanaan hingga pelaksanaan sampai melahirkan produk berupa alat angkut tradisional dapat diselesaikan dalam kurun waktu satu tahun. Kegiatan operasional di lapangan 
akan ditemukan berbagai kekurangan dari segi pengoperasional alat angkut, maka tetap dilakukan penyempurnaan diberbagai komponen alat yang terpasang agar alat angkut fungsional (kuat dan tahan) dari semua medan dimanapun dioperasikan oleh petani. Kekurangan dari hasil produksi pertama ini akan dilakukan penyempurnaan pada desain yang baru di tahun berikutnya.

Alat angkut tradisional diperuntukkan untuk petani mandiri khususnya di lahan gambut, bilamana medan yang sangat berat pada musim hujan dengan asumsi curah hujan yang tinggi membuat roda tidak bisa berfungsi normal, maka akan dipikirkan untuk dikembangkan suatu alat angkut yang bergerak (beroperasi) di sungai kecil yang banyak terdapat di lahan pertanian, dimana sungai atau lebih tepatnya parit kecil ini selain menjadi pembatas tanah garapan juga dapat berfungsi sebagai jalur transportasi air untuk mengeluarkan buah dari lahan petani. Direncanakan akan ada suatu modifikasi alatangkut yang berkapasitas besar, mudah dikendalikan, serta tidak memerlukan air yang dalam untuk bisa dioperasikan. Petani sawit di lahan gambut diharapkan tidak lagi merasa terganggu atas kondisi cuaca baik musim hujan maupun musim kemarau di dalam menjual hasil pertanian karena petani telah diberikan pilihan dalam penggunaan alat angkut sederhana berbasis bahan bekas pakai.

\section{KESIMPULAN}

Alat angkut tradisional dengan menggunakan bahan baku barang bekas dari berbagai jenis kendaraan roda empat, sangat efektif untuk digunakan dan dikembangkan guna membantu petani sawit di lahan gambut. Efektifitas alat angkut ini dapat dilihat dari lama waktu panen hingga pengangkutan buah ke pabrikyang semula memerlukan waktu hingga 4 sampai 5 hari, dengan adanya alat angkut tradisional ini dapat dipersingkat waktunya menjadi dua hari. Proses pemanenan yang biasanya menggunakan waktu 12 hari (satu periode putaran) pada lahan $5 \mathrm{Ha}$, namun setelah memanfaatkan alat angkut tradisional ini dapat dihemat waktunya hingga 50\% (dapat diselesaikan dalam waktu enam hari). Pendapatan petani dapat meningkat, karena jumlah produksi lebih banyak dibanding saat mereka menggunakan alat biasa berupa arco, drum plastik, dan lanjung yang cukup menyita tenaga. Pemotongan harga buah yang dialami oleh petani tidak ada, disebabkan karena buah yang restan (biji sawit yang sudah lepas dari tandannya). Kualitas buah sampai ke pabrik adalah kualitas baik dengan buah tandang yang masih segar, diikuti harga yang tinggi. Petani juga dapat memanfaatkan alat angkut ini untuk keperluan dalam memobilisasi tenaga kerja ke lokasi lainnya yang memerlukan perawatan secara berkala. Artinya petani tidak perlu lagi berjalan kaki untuk pindah dari satu lokasi ke lokasi yang lainnya, karena mereka dapat memanfaatkan alat angkut tradisional ini untuk berpindah bekerja ke tempat lain. Alat angkut tradisional ini selain mengangkut buah juga dapat digunakan untuk mengangkut bahan-bahan seperti pupuk, racun rumput, air, dan keperluan perawatan kebun. Perawatan yang kontinu untuk menjaga keberlangsungan alat pada lahan yang tingkat kelembapannya cukup tinggi, agar tidak cepat keropos seperti pemberian pelumas ataupun penyemprotan solar khusunya pada daerah yang mudah keropos. Modifikasi pada bagian depan (dudukan mesin) untuk kesempurnaan desain alat angkut agar dapat terlihat dengan rapi baik di lihat dari depan maupun dari samping. Pengembangan ke depan alat angkut ini perlu diberikan lampu berupa lampu stop dan lampu reting lampu jalan agar disaat berada pada jalan raya dapat lebih terjaga keamanannya baik pengendara maupun alat angkutnya. Rem pada bagian belakang (ban belakang) juga perlu diberikan, jadi dalam 
sistem pengereman tidak hanya bertumpu pada bagian depan, tetapi ada juga sitem pengereman di bagian belakang. Atap pelindung sinar matahari atau bendabenda lainnya khususnya bagi pengemudi juga perlu diberikan, mengingat sengatan matahari sangat tinggi perlu adanya pelindung yang membuat pengemudinya bekerja dengan lebih tenang.

\section{UCAPAN TERIMA KASIH}

Selesainya kegiatan pengabdian kepada masyarakat, kami dari tim kerja menyampaikan ucapan terima kasih kepada Kementerian Riset dan Teknologi (Ristekdikti) lewat kegiatan PPM yang telah memberikan dana untuk melaksanakan kegiatan hingga tuntas. Demikian pula ucapan terima kasih kami sampaikan kepada anggota kelompok tani Pelangi Nusantara kabupaten Pulang Pisau yang telah memberikan kepercayaan kepada Tim dalam mencari solusi atas kendala yang dihadapi dalam mengelola perkebunan, selama ini petani dihadapkan dengan kesulitan mengangkut hasil produksi dari kebun menuju tempat penumpukan buah. Ucapan yang sama kami sampaikan juga terima kasih kepada Rektor Universitas Palangka Raya lewat LPPM Universitas Palangka Raya yang telah memberikan kesempatan untuk mengakses kegiatan penelitian/pengabdian kepada masyarakat. Semoga alat angkut tradisional yang berbasis bahan bekas bermanfaat untuk petani khususnya mitra.

\section{REFERENSI}

Colchester, M., Chao, S., Dallinger, J., Sokhannaro, H.E.P., Dan, V.T., Villaneuva, J. 2011. Ekspansi Kelapa Sawit di Asia Tenggara: Kecenderungan dan implikasi bagi masyarakat lokal dan masyarakat adat. Bogor: Forest Peoples Programme \& Perkumpulan Sawit Watch.

Darwis, V., Nurmanaf, A.R. 2004. Aktivitas Dan Sumber Pendapatan Petani Miskin Berlahan Sempit Di Daerah Sawah Tadah Hujan Dataran Rendah
(Kasus: Dua Desa di Kabupaten Bojonegoro). SOCA: Jurnal Sosial Ekonomi Pertanian. 4(3):119.

Fadhil, R., Mustaqimah, Putra, B.S., Syafriandi, Lubis, A., Al-Qudri, Fikri, M. 2015. Evaluasi Kinerja Gerobak Sorong Bermesin Untuk Pengangkutan Tandan Buah Segar Kelapa Sawit (Elaeis guineensis jacq.). Agrotekno. 17(2):1-7.

Gunawan, R., Thamrin, J., Suhendar, E. 1998. Industrialisasi Kehutanan Dan Dampaknya Terhadap Masyarakat Adat: Kasus Kalimantan Timur. Bandung: Akatiga.

Hermanto, Swastika, D.K.S. 2011. Penguatan Kelompok Tani: Langkah Awal Peningkatan Kesejahteraan Petani. Analisis Kebijakan Pertanian. 9(4):371-390. http:/ /dx.doi.org/10.21082/akp.v9n4.2011.37 $1-390$

Irawati, E., Yantu, M.R. 2015. Kinerja Kelompok Tani Dalam Menunjang Pendapatan Usahatani Padi Sawah Di Desa Sidera Kecamatan Sigi Biromaru Kabupaten Sigi. Agrotekbis : E-Jurnal Ilmu Pertanian. 3(2):206-211.

Kamuntuan, N., Ionda, V.Y., Tampongangoy, D.L. 2017. Pemberdayaan Kelompok Tani Di Desa Tolombukan Kecamatan Pasan Kabupaten Minahasa Tenggara. Jurnal Administrasi Publik. 3(46):1-11.

Pratama, B.P., Sayamar, E., Tety, E. 2016. Peran Kelompok Tani Dalam Meningkatkan Pendapatan Petani Swadaya Kelapa Sawit Di Desa Bukit Lingkar Kecamatan Batang Cenaku Kabupaten Indragiri Hulu. Jurnal Online Mahasiswa Fakultas Pertanian Universitas Riau. 3(2):1-12.

Pudjianto, B. 2006. Pemetaan Sosial di Kecamatan Sebangau Kuala, Kabupaten Pulang Pisau Provinsi Kalimantan Tengah. Jurnal Penelitian dan Pengembangan Kesejahteraan Sosial. 11(2):4858.

Suharyanto, Rinaldy, J., Arya, N.N. 2016. Analisis Risiko Produksi Usahatani Padi Sawah di Provinsi Bali. AGRARIS: Journal of Agribusiness and Rural Development Research. 1(2):70-77. https://doi.org/10.18196/agr.1210 